\title{
Dinamika Sosial Terhadap Rencana Pemekaran Wilayah Tanah Duri
}

\author{
Herianto \\ Irwan Akib \\ Universitas Muhammadiyah Makassar \\ irwanakib@unismuh.ac.id \\ Abd. Aziz Muslimin \\ Universitas Muhammadiyah Makassar \\ azizmuslimin@unismuh.ac.id
}

\begin{abstract}
ABSTRAK
Penelitian ini bertujuan untuk mengetahui Dinamika Sosial Rencana Pemekaran Wilayah Tanah Duri Di Kabupaten Enrekang dan untuk mengetahui penyebab munculnya wacana Pemekaran Kabupaten Enrekang serta untuk mengetahui kendala-kendala dalam merealisasikan rencana pemekaran Tanah Duri di Kabupaten Enrekang.Metode peneltian ini menggunakan penelitian kualitatif dimana penelitian kualitatif merupakan penelitian yang tidak menggunakan sumber datanya berupa angka-angka melainkan menggunakan penggambar yang terjadi dilapangan melalui wawancara, dokumentasi, dokumentasi, dan lain-lain.Sumber data yang digunakan adalah data primer dan data skunder.Hasil penelitian dilapangan menunjukan bahwa dinamika sosial terhadap rencana pemekaran wilayah Tanah Duri di Kabupaten Enrekang mengalami prokontrak dari masyarakat, oleh karena itu harus mendapat perhatian khusus dari pemerintah sehingga ada solusi yang tepat.Berdasarkan hasil penelitian tersebut diatas, dapat disimpulkan bahwa rencana pemekaran Tanah Duri di Kabupaten Enrekang menimbulkan dinamika sosial di dalam masyarakat dan rencana tersebut muncul karena beberapa faktor penyebab serta untuk merealisasikan rencana tersebut terdapat beberapa kendala-kendala yang kemudian di rasakan oleh masyarakat di kabupaten Enrekang.
\end{abstract}

Kata Kunci: Dinamika Sosial, Otonomi Daerah, Rencana Pemekaran Daerah.

\section{PENDAHULUAN}

Sejak diberlakukannya Undang-Undang Nomor 22 Tahun 1999 yang kemudian diamandemen menjadi Undang-Undang No.32 Tahun 2004 tentang otonomi daerah, banyak daerah di Indonesia yang mengusulkan diri untuk menjadi daerah otonom baru dengan tujuan mendapatkan kewenangan yang lebih besar dalam mengupayakan pembangunan dan kesejahteraan bagi daerahnya. Pembentukan daerah otonomi baru atau yang biasa disebut pemekaran daerah yang memungkinkan daerah untuk mengelola sumber daya nasional yang tersedia di wilayah masing-masing.Dalam Pasal 10 UndangUndang No.32 Tahun 2004 disebutkan bahwa daerah memiliki wewenang untuk mengelola dan memelihara sumber daya nasional yang dimilikinya sesuai dengan peraturan perundang-undangan.Selain itu daerah berhak mengatur dan mengurus 
kepentingan masyarakat berdasarkan prakasa sendiri dan aspirasi masyarakat dalam ikatan Negara Kesatuan Republik Indonesia.Artinya, otonomi daerah memberikan pelimpahan wewenang baik dalam pengambilan kebijakan maupun keputusan pembiayaan kepada daerah dan berusaha melibatkan masyarakat dalam upaya pembangunan daerah sehingga kohesi sosial antara politik dan masyarakat semakin kuat.

Begitupun Kabupaten Enrekang, gagasan pemekaran Kabupaten Enrekang dan pembentukan Kabupaten Duri Massenrenpulu kembali diwacanakan sejumlah kalangan. Alasan-alasan pemekaran Kabupaten Enrekang menurut para penggagasnya yakni alasan mendekatkan dan memudahkan pelayanan kepada masyarakat.Hal ini dijadikan alasan utama karena adanya kendala geografi, infrastruktur dan sarana perhubungan yang minim. Kondisi ini persis dialami oleh wilayah Kabupaten Enrekang yang faktanya memang sebagian besar berada di pegunungan. Kondisi ini menyebabkan pembangunan infrastruktur seperti, jalan, jembatan, sekolah, kantor, puskesmas, dan lain-lain. Kondisi geografi ini menyebabkan anggaran pembangunan untuk daerah dengan kondisi geografi seperti ini berlipat.Namun sayangnya, kondisi geografi dengan tantangan alam yang sulit ini tidak pernah diperhitungkan dalam kebijakan alokasi anggaran dari pusat untuk daerah seperti Enrekang. Oleh karena itu kita harus memikirkan bagaimana mengalirkan dana kedaerah kita yang tantangan pembangunannya yang berlipat ini. Dan solusi paling tepat adalah pemekaran Kabupaten. Dalam hal tersebut tak bisa di pungkiri Wacana Rencana Pemekaran Tanah Duri di Kabupaten Enrekang akan terjadi dinamika sosial di dalam masyarakat, khususnya masyarakat Tanah Duri yang rencana menjadi titik pemekaran daerah yang menjadi wacana masyarakat dan pemerintah. Namun tidak bisa dipungkiri sebagian masyarakat dan pemerintah sangat mengharapkan program atau wacana tersebut agar terlaksana, dengan harapan program pemekaran daerah yang dilaksanakan oleh pemerintah Enrekang ini dapat merubah pembangunan daerah kearah yang lebih baik melihat bahwa daerah ini sangat mendukung dengan adanya program pemerintah dalam pemekaran daerah dan dapat juga merubah tarap perubahan sosial kearah yang positif dalam mensejahtrakan rakyat, akan tetapi sebagian masyarakat tidak mengharapkan pemekaran itu terjadi sehingga akan memberikan dampak di berbagai bidang.

\section{PENDAHULUAN}

Dalam Undang-undang No. 32 Tahun 2004 tentang pemerintahan daerah pasal 1 poin 5, bahwa otonomi daerah adalah, Hak, wewenang dan kewajiban daerah otonom untuk mengurus sendiri urusan pemerintahan dan kepentingan masyarakat setempat 
sesuai dengan peraturan perundang-undangan. Sedangkan pada poin 6, bahwa Desentralisasi adalah penyerahan wewenangan pemerintah oleh pemerintah kepada daerah otonom untuk mengatur dan mengurus urusan pemerintah dalam Sistem Negara Republik Indonesia.Otonomi daerah dilaksanakan oleh daerah otonom, dimana daerah otonom adalah kesatuan masyarakat hukum yang mempunyai batas daerah tertentu berwenang mengatur dan mengurus kepentingan masyarakat setempat menurut prakarsa sendiri berdasarkan aspirasi masyarakat dalam Ikatan Negara Kesatuan Republik Indonesia.Hal ini memberikan kewenangan penuh kepada daerah otonomi melalui pemerintah daerahnya untuk melaksanakan pembangunan daerahnya sesuai ketentuan Visi misi otonomi daerah.Dalam UU No. 32 Tahun 2004.Pemekaran wilayah/ daerah atau pembentukan Daerah Otonom Baru (DOB) di era reformasi merupakan konskuensi logis dari penerapan kebijakan desentralisasi politik oleh pemerintah pusat di daerah. Dengan desentralisasi politik maka pemerintah pusat membentuk daerah-daerah otonom atau daerah-daerah yang mempunyai pemerintahan, yaitu daerah-daerah yang mempunyai wilayah, masyarakat hukum, kepala daerah, dan anggota DPRD yang dipilih oleh rakyat, pegawai, dan kewenangan serta keleluasaan mengatur dan mengurus daerah. Ruang bagi daerah untuk mengusulkan pembentukan Daerah Otonom Baru dibuka lebar oleh kebijakan pemekaran daerah berdasar UU No. 32 Tahun 2004. Dengan kebijakan yang demikian ini, kebijakan pemekaran daerah sekarang lebih didominasi oleh proses politik daripada proses teknokratis.

Dalam Haw. Widjaja (2013: 18-19), pembentukan daerah yang secara serentak merupakan kelahiran status otonomi yang didasarkan atas aspirasidan kondisi objektif dari masyarakat di daerah atau wilayah tertentu sebagai bagian dari bangsa dan wilayah nasional Indonesia.Aspirasi tersebut terwujud dengan diselenggarakannya desentralisasi menjelma menjadi daerah otonom. Oleh karena itu, otonomi daerah adalah sebagai kesatuan masyarakat hokum yang berwenang mengatur dan mengurus kepentingan masyarakat setempat menurut prakarsa sendiri berdasarkan aspirasi masyarakat.Dengan demikian, desentralisasi sebenarnya menjelma otonom masyarakat setempat untuk memecahkan sebagai masalah dan pemberian layanan yang bersifat lokalitas demi kesejahteraan masyarakat.

Menurut adam dalam Judistira (1962: 122), dinamika sosial merupakan kekuatan organisasi manusia dalam aktivitas bersama dari kelompok fungsional yang menunjukkan perhatian manusia seperti tercakup dalam menjalankan fungsi sosial mereka. Perhatian manusia itu tampak sebagai rangkaian logis pada setiap tahapan kehidupan membentuk 
dasar ilmiah yang menjadi kerangka acuan bagi setiap klasifikasi fungsi manusia.Peluang dan institusi yang merupakan satuan dinamika dari organisasi sosial, sistem dasar kekuatan alamiah tersebut. Dalam Narwoko (2011: 306), Dinamika sosial merupakan masalah-masalah sosial yang tetap terjadi dalam suatu masyarakat. Masalah sosial berkaitan dengan norma dan institusi sosial, artinya sesutu itu di angap sebagai masalah sosial karena menyangkut hubungan manusia dengan nilai-nilai dan merupakan gangguan tujuan kehidupan masyarakat.masalah sosail atau social problems ialah setiap keadaan yang di anggap oleh seluruh atau sebagian warga masyarakat sbagai suatu keadaan yang tetap dikehendaki,tak dapat di toleransi, atau di anggap ancaman bagi nilai-nilai dasar masyarakat, sehingga memerlukan tindakan masyarakat untuk menyelesaikanya.

Dalam Ritzer, (2014: 256-257), Fungsionalisme Struktural Parsons mengenal empat fungsi penting untuk semua system dan terkenal dengan istilah AGIL. Fungsifungsi penting tersebut ialah Adaptation, Goal Atteinment, Integration, dan Latency.

1. Adaptation ( adaptasi) adalah Sistem harus mengatasi kebutuhan situasional yang dating dari luar. Ia harus beradaptasi dengan lingkungan dan menyesuaikan lingkungan dengan kebutuhan-kebutuhannya.

2. Goal Atteinment (Pencapaian tujuan), adalah Sistem harus mendefenisikan dan mencapai tujuan-tujuan utamanya.

3. Integration (integrasi), adalah Sistem harus mengatur hubungan bagian-bagian yang menjadi komponennya. Ia pun harus mengatur hubungan antar ketiga imperatig fungsional tersebut. ( A. G. I. L).

4. Latency( pemeliharaan pola), adalah Sistem harus melengkapi, memelihara, dan memperbahrui motivasi individual maupun pola-pola kultural yang menciptakan dan menopang motivasi tersebut.

Dalam Ritzer, (2014: 257), Parson mendesain skema AGIL agar dapat digunakan pada semua level sistem teoritisnya. Organisme behavioral adalah sistem tindakan yang menangani fungsi adaptasi dengan menyesuaikan dan mengubah dunia luar.Sistem kepribadian menjalankan fungsi pencapaian tujuan dengan mendefenisikan tujuan sistem dan memobilisasi sumber daya yang digunakan untuk mencapainya.Sistem sosial menangani fungsi integrasi dengan mengontrol bagian-bagian yang menjadi yang menjadi komponennya.Akhirnya, sistem kultural menjalankan fungsi latensi dengan membekali actor dengan nilai dan norma-norma yang memotivasi mereka untuk bertindak. 


\section{METODE PENELITIAN}

Jenis penelitian yang dilakukan penelitian deskriptif kualitatif yang bertujuan untuk mengetahui Dinamika Sosial Rencana Pemekaran Wilayah Tanah Duri Di Kabupaten Enrekang dan untuk mengetahui penyebab munculnya wacana Pemekaran Kabupaten Enrekang serta untuk mengetahui kendala-kendala dalam merealisasikan rencana pemekaran Tanah Duri di Kabupaten Enrekang.Informan ditentukan secara purposive sampling tehnik pengumpulan data yaitu observasi, wawancara dan dokumentasi, kemudian dianalisis melalui analisis data dan menggunakan tehnik keabsahan data triangulasi sumber, metode, dan teori.

\section{PEMBAHASAN}

1. Dinamika Sosial terhadap rencana pemekaran Tanah Duri di Kabupaten Enrekang.

Dinamika sosial terkait rencana pemekaran Tanah Duri di Kabupaten Enrekang dapat dilihat dari hasil penelitian bahwa terdapat prokontra baik masyarakat, mahasiswa maupun pemerintah terkait rencana pemekaran tersebut terkhusus masyarakat yang berdomisili di Kecamatan Baraka sebagai tempat penelitian.Sebagaian besar masyarakat, mahasiswa dan pemerintah setuju dengan rencana pemekaran yang kemudian menjadi isu di kabupaten Enrekang namun sebagian besar juga tidak setuju dengan rencana pemekaran Tanah Duri tersebut. Dinamika sosial terkait rencana pemekaran Tanah Duri di Kabupaten bahwa masalah masih berada dalam suasana atau kondisi yang kondusif yang tetap di perlihatkan oleh masyarakat, mahasiswa maupun pemerintah Kabupaten Enrekang secara umum dan masyarakat di Kecamatan Baraka secara khusus. Kondisi tersebut sangat mempengaruhi langkah pemerintah dalam merealisasikan rencana pemekaran tersebut sehingga tidak hanya sekedar menjadi rencana belaka di Kabupaten Enrekang.

Pemberian otonomi daerah kepada setiap daerah akan memberikan implikasi positif bagi dinamika aspirasi masyarakat di Kabupaten Enrekang. Kebijakan daerah tidak lagi bersifat given dan uniform (selalu menerima dan seragam) dari pemerintah pusat, namun justru pemerintah daerah yang mesti mengambil inisiatif dalam merumuskan kebijakan daerah yang sesuai dengan aspirasi, potensi dan sosio-kultural masyarakat di Kabupaten Enrekang tepatnya di Tanah Duri. Undang-undang ini juga membuka jalan bagi terselenggaranya pemerintahan yang baik (good governance) di satu pihak dan pemberdayaan ekonomi rakyat di pihak lain. Karena dengan otonomi, pemerintahan kabupaten Kabupaten Enrekang memiliki kewenangan yang memadai untuk 
mengembangkan program-program pembangunan berbasis masyarakat (ekonomi rakyat).Jika selama ini program-program pemberdayaan ekonomi rakyat didisain dari pusat, tanpa daerah memiliki kewenangan untuk berkreasi.Sekarang saatnya pemerintah daerah kabupaten Enrekang menunjukkan kemampuannya terutama Tanah Duri yang menjadi isu rencana pemekaran. Tantangan, bahwa daerah mampu mendisain dan melaksanakan program yang sesuai dengan kondisi lokal patut disikapi dengan kepercayaan diri dan tanggung jawab penuh. Rencana pemekaran Tanah Duri di Kabupaten Enrekang menjadi salah satu isu pemerintah daerah, alasannya bahwa pemerintah daerah yang luas akan mampu secara efektif membuat public policies disegala bidang ataupun mampu melaksanakan kebijakan-kebijakan secara efektif dan efesien di seluruh wilayah yang ada di kabupaten Enrekang. Demikian halnya di dalam manajemen penyelenggaraan pemerintahan dan pembangunan. Pola-pola penyelenggaraan pemerintah dan pembangunan yang sentralistik menjadi kurang aktual, sehingga perlu desentralistik yang berdampak kepada kurangnya masalah-masalah yang timbulnya di dalam masyarakat.

Penyebab munculnya wacana Pemekaran Tanah Duri Kabupaten Enrekang

Rencana pemekaran Tanah Duri di kabupaten pada pada dasarnya merupakan upaya meningkatkan kualitas dan intensitas pelayanan pada masyarakat. Dari segi pengembangan wilayah, dinilai oleh semua pihak memiliki basis sumber daya yang seimbang antara satu dengan yang lain. Hal ini menjadi salah satu penyebab rencana pemekaran tersebut. Selanjutnya dalam suatu usaha pemekaran wilayah akan diciptakan ruang publik baru yang merupakan kebutuhan kolektif semua warga wilayah baru. Ruang publik baru ini akan mempengaruhi aktivitas seseorang atau masyarakat sehingga merasa diuntungkan karena pelayanannya yang lebih maksimal. setiap rencana pemekaran di seluruh daerah Berdasarkan beberapa penyebab rencana pemekaran Tanah Duri, dapat disimpulkan bahwa pemerintah Kabupaten Enrekang dan mahasiswa serta masyarakat yang mendiami daerah Tanah Duri secara umum dan masyarakat yang mendiami wilayaha Kecamatan Baraka mempunyai alasan atau faktor sehingga ingin memisahkan diri dari wilayah induk, salah satunya karena mereka berkeyakinan bahwa daerah Duri selalu di marjinalkan oleh daerah kota padahal Tanah Duri memiliki potensi sumber daya yang sangat memadai baik sumber daya alam maupun manusia itu sendiri. 
2. Kendala-Kendala Dalam Merealisasikan Rencana Pemekaran Tanah Duri Di Kabupaten Enrekang

Dalam kenyataannya bahwa ternyata rencana pemekaran Tanah Duri di Kabupaten Enrekang membuktikan bahwa ternyata selama perjalanannya, otonomi daerah termasuk isu pemekaran daerah Tanah Duri sebagai solusi untuk peningkatan kesejahteraan dan peningkatan kualitas pelayanan kepada masyarakat tidak segampang membalikkan telapa tangan. Hal tersebut tidak terlepas dari berbagi kendala- kendala sesuai hasil penelitian yang muncul terkait pemekaran tersebut, Pemerintah daerah mengalami beberapa kendala dalam merealisasikan Tanah Duri menjadi salah satu Kabupaten di Bumi Massenrenpulu sebagai berikut:

a. Pemerintah belum memberikan sosialisasi secara rutin kepada masyarakat.

b. Rencana penempatan ibu kota Kabupaten Tanah Duri belum jelas sehingga pemerintah dan masyarakat harus mencari solusi bersama.

c. Sumber daya alam di wilayah induk tidak memadai jika Tanah Duri memisahkan diri karena Duri merupakan penghasil beras dan sayur-sayuran di Kabupaten Enrekang.

d. Pembebasan tanah atau lokasi yang akan ditempati membangun kantor pemerintahan seperti kantor Bupati, DPR dan instansi pemerintah lainnya.

Kemudian ketika ditinjau secara umum, pemberian otonomi daerah dimaksudkan untuk meningkatkan pelayanan dan kesejahteraan masyarakat yang semkain baik, pengembangan kehidupan demokrasi, keadilan, pemerataan, serta pemeliharaan hubungan yang serasi antara pusat dan daerah serta antara daerah dan daerah dalam rangka menjaga keutuhan Negara Kesatuan Republik Indonesia. Tetapi pada pelaksanaannya kebijaksanaan otonomi daerah memiliki beberapa kendala, antara lain adalah belum memadainya regulasi atau peraturan pelaksanaan kebijaksanaan Otonomi Daerah, terdapatnya inkonsistensi Pemerintah Pusat dalam melaksanakan kebijaksanaan Otonomi Daerah, belum terdapatnya persamaan persepsi dalam menafsirkan kebijaksanaan Otonomi Daerah dari berbagai kalangan, terbatasnya kemampuan SDM dalam melaksanakan kebijaksanaan Otonomi Daerah.Tetapi, tetap saja otonomi daerah masih terus diberikan kepada setiap daerah yang ingin memisahkan diri dari wilayah induk. Seringkali pemberian otonomi daerah tidak memperhatikan kemampuan daerah itu. Seperti yang banyak terjadi dengan daerah - daerah otonom yang ada saat ini. Salah satunya adalah banyaknya masalah yang timbul akibat pemekaran daerah kabupaten/kota dan provinsi di Indonesia. Terbukti setelah Departemen Dalam Negeri (Depdagri) melakukan evaluasi terhadap 148 daerah otonomi atau hasil pemekaran dari 98 yang telah 
dievaluasi oleh pemerintah dan ternyata 76 diantaranya bermasalah. Salah satu penyebab adalah belum tercapainya angka potensi kemampuan ekonomi. Selain itu, ada 87,71 persen daerah induk belum menyelesaikan P3D (Pembiayaan, Personil, Peralatan, dan Dokumen). Kemudian, 79 persen daerah otonomi baru belum memiliki batas wilayah yang jelas. Selanjutnya, 89,48 persen daerah induk belum memberikan dukungan dana kepada daerah otonomi baru. Kemudian, 84,2 persen pegawai negeri sipil (PNS) sulit dipindahkan dari daerah induk ke daerah pemekaran. Dan juga terdapat beberapa daerah yang melanggar undang-undang pembentukan daerah, daerah-daerah itu masih belum menempati ibu kota daerah yang telah ditentukan undang-undang. Dalam hal ini, Tanah Duri tetap ingin memisahkan diri dari daerah induk meskipun terdapat kendala-kendala yang di alami dalam merealisasikan rencana tersebut, salah satu kendalanya yakni penempatan ibu kota Kabupaten Tanah Duri serta sosialisasi yang masih kurang sehingga pemerintah dan masyarakat harus mencari solusi bersama untuk mengatasi kendalakendala tersebut jika benar-benar ingin menjadikan Tanah Duri sebagai salah satu Kabupaten di Bumi Massenrenpu.

\section{KESIMPULAN}

Bertolak dari hasil penelitian tentang Dinamika Sosial Rencana Pemekaran Wilayah Tanah Duri Di Kabupaten Enrekang (Studi Kasus Masyarakat Di Kecamatan Baraka Kabupaten Enrekang) yang telah dilaksanakan dan yang menjadi informan yakni ,pemerintah, mahasiswa dan masyarakat yang mendiami Kecamatan Baraka. Melalui kegiatan observasi, wawancara dan dokumentasi terhadap beberapa informan yang telah di tetapkan sebelumnya sebagai informan penelitian yang merupakan sumber informasi utama dapat disajikan data hasil penelitian mengenai dinamika sosial terhadap rencana pemekaran wilayah Tanah Duri di Kabupaten Enrekang (Studi Kasus Masyarakat Di Kecamatan Baraka). Maka peneliti dapat menyimpulkan sebagai berikut:

1. Dinamika sosial yang terjadi di masyarakat terkait rencana pemekaran Tanah Duri di Kabupaten Enrekang adalah terjadinya prokontra, ada yang kemudian setuju dan ada yang tidak setuju dengan berbagai alasan dan pertimbangan.

2. Salah satu penyebab rencana pemekaran Tanah Duri di Kabupaten Enrekang adalah masalah pelayanan terhadap masyarakat yang di rasa memuaskan serta masyarakat Tanah Duri merasa di marjinalkan oleh pemerintah padahal Tanah Duri memiliki potensi sumber daya yang sangat memadai baik sumber daya alam maupun manusia itu sendiri 
3. Dalam merealisasikan rencana pemekaran Tanah Duri di Kabupaten Enrekang teori fungsionalisme Taclott Parsons memberikan sumbangsi terkait rencana pemekaran tersebut yaitu adaptation sangat dibutuhkan oleh masyarakat dan pemerintah untuk beradaptasi dengan situasi dan kondisi, Goal attainment berfungsi untuk mencapai tujuan masyarakat serta pemerintah, Integrastion berfungsi memelihara pola ataupun semangat yang membara dari semua pihak, baik pemerintah maupun masayarakat dan Laten berfungsi untuk memelihara hubungan semua pihak baik masyarakat maupun pemerintah yang mendiami Tanah Duri maupun Enrekang kota.

\section{DAFTAR PUSTAKA}

Andry Pramudya. (2012). Defenisi Masyarakat. (Online) http: // Sosial Sosiologi. Blogspot.com/2012/12/defenisi masyarakat.html, diakses 20 Mei 2015 Pukul 00.45)

Anwar Yesmil dan Adang.(2013). Sosiologi Untuk Universitas.Bandung : PT Refika Aditama.

Damsar.(2012). Pengantar Sosiologi Politik.Jakarta : Kencana Prenada Media Group.

Douglas J. Goodman, George Ritzer. (2014). Teori Sosiologi.Jakarta : Lembaga Kreasi Penerbit Masyarakat.

Julia Panglima Saragih. (2003). Desentralisasi fiskal dan keuangan dalam otonomi daerah . Jakarta: Ghali Indonesia.

Kaho Josef Riwu. (1988). Prospek Otonomi Daerah Di Negara Republik Indonesia. Jakarta: PT Rajagrafindo Perseda.

Kaloh K. (2007). Mencari Bentuk Otonomi Daerah. Jakarta: Rineka Cipta.

Martono Nanang. (2011). Sosiologi Perubahan Sosial.Jakarta : Rajawali Pers.

Moleong, J.Lexy. (2007). Metode Penelitian Kualitatif.Bandung : Rosdakarya.

Ranjabar Jacobus. (2013). Sistem Sosial Budaya Indonesia Suatu Pengantar. Bandung: Alfabeta.

Seksi Integrasi Pengelolah dan Diseminasi Statistik.(2010). Kabupaten Enrekang Dalam angka 2010. Makassar: UD Areso Makassar.

Soekanto Soerjono. (2012). Sosiologi Suatu Pengantar.Jakarta : PT. Raja Grafindo Persada.

Suyanto Bagong \&Dwi Narwako. (2011). Sosiologi Teks Pengantar dan Terapan.Jakarta : Kencana. 
Syarbaini Syahrial, Rusdiyanta. (2009). Dasar-dasar Sosiologi.Yogyakarta. Graha Ilmu.

Tim Penyusun FKIP Unismuh Makassar.(2015). Pedoma Penulisan Skripsi. Makassar: Panrita Press Unismuh Makassar.

Undang-undang Republik Indonesia No. 32 Tahun 2004 tentang Pemerintah Daerah

Ventauli. (2009). Mengelola Dinamika Politik dan Sumber Daya Daerah .Yogyakarta : Program S2 Politik Lokal dan Otonomi Daerah UGM.

Wahyudin. Udin.( 2008). pemekaran kecamatan Parigi. skripsi. Makassar: universitas negeri Makassar.

Wijaya. Haw. (2013). Penyelenggaraan Otonomi Di Indonesia . Jakarta: PT Raja Grafindo Persada.

Zulfaidah Idriana. (2013). Pengertian Unsur-Dan-Kriteria-Masyarakat. (online) http://zulfaidaindriana. Blogspot.com/2013/05/pengertian unsur dan kriteria masyarakat.html, diakses 16 Mei 2015 Pukul 20.00 WITA. 